\title{
FENOMENA MEDIA SOSIAL: ANTARA HOAX, DESTRUKSI DEMOKRASI, DAN ANCAMAN DISINTEGRASI BANGSA
}

\author{
Febriansyah $^{1)}$ dan Nani Nurani Muksin' ${ }^{2)}$ \\ ${ }^{1,2}$ Program Studi Magister Ilmu Komunikasi, Fakultas Ilmu Sosial dan Ilmu Politik, Universitas Muhammadiyah Jakarta \\ ${ }^{1,2}$ Jalan KH. Ahmad Dahlan, Cirendeu, Tangerang Selatan, Banten, Indonesia, 15419 \\ E-mail: febriansyah2014@gmail.com ${ }^{1)}$, nanimuksin@gmail.com ${ }^{2}$
}

\begin{abstract}
ABSTRAK
Teknologi digital (internet) berkembang sangat pesat, termasuk media sosial. Hal tersebut dapat dilihat dari pengguna media sosial yang setiap waktu mengalami peningkatan cukup signifikan. Demikian pula dengan fenomena yang ditimbulkan akibat dari hadirnya media sosial tersebut, ragam masalah penggunaan media sosial turut hadir di dalamnya, termasuk maraknya hoax (berita bohong). Belakangan ini produksi dan penyebaran hoax atau berita bohong semakin tidak terbendung dan media sosial menjadi sarana yang paling banyak digunakan untuk menyebarkan hoax. Penelitian ini bertujuan untuk menjelaskan fenomena media sosial yang menjadi saluran terbesar dalam penyebaran hoax dan dampaknya bagi kelangsungan hidup demokrasi serta potensi ancaman disintegrasi bangsa. Penelitian ini menggunakan teori media sosial, dengan pendekatan kualitatif bersifat deskriptif, yaitu untuk melihat, menganalisis, dan mendeskripsikan data dan fakta yang terjadi mengenai fenomena maraknya hoax dan penyebarannya melalui media sosial, serta menjelaskan akibatnya terhadap penurunan demokrasi di Indonesia dan potensi ancaman keutuhan bangsa. Hasil penelitian menunjukkan bahwa media sosial menjadi media yang paling diminati dalam mengakses informasi. Selain itu, kecepatan dan kemudahan, serta konten dari pengguna menjadikan media sosial sebagai media yang paling banyak menyebarkan hoax, hal ini terbukti dari banyaknya contoh kasus penyebaran hoax di media sosial. Penyebaran berita hoax ini sangat meresahkan masyarakat, dampaknya tidak hanya terjadi kegaduhan di tengah-tengah masyarakat, tetapi juga dapat merusak (destruksi) kualitas demokrasi di Indonesia, bahkan berpotensi mengakibatkan perpecahan (disintegrasi) bangsa.
\end{abstract}

Kata Kunci: Media Sosial, Hoax, Destruksi Demokrasi, Disintegrasi Bangsa, Social Media

\section{PENDAHULUAN}

Teknologi Informasi dan Komunikasi (TIK) mengalami perkembangan yang sangat pesat, terutama perkembangan teknologi digital (internet). Hal ini dapat dilihat dari jumlah pengguna internet yang setiap waktu mengalami peningkatan secara signifikan. Berdasarkan data dari aseanup.com pada bulan Januari 2017 pengguna internet di Indonesia mencapai 132,7 juta orang, dengan pengguna media sosialnya sebanyak 106 juta orang. Mengalami peningkatan pada tahun 2018, menurut data Asosiasi Penyelenggara Jasa Internet Indonesia (APJII), pengguna internet di Indonesia mengalami peningkatan mencapai 171,17 juta orang.

Berdasarkan global digital report tahun 2020 dari WeAreSocial dan Hoot suite, terungkap bahwa pengguna internet telah mencapai 4,5 miliar orang di seluruh dunia. Angka ini menunjukkan bahwa pengguna internet telah lebih dari separuh populasi bumi, atau sekitar lebih dari 60 persen penduduk dunia. Sebagian besar dari pengguna internet tersebut merupakan pengguna media sosial, dengan jumlah 3,8 miliar orang. Di Indonesia, masih menurut sumber yang sama, pengguna internet pada tahun 2020 mencapai 175,4 juta orang dari jumlah total penduduk Indonesia sekitar 272,1 juta orang. Artinya, sekitar 64 persen penduduk Indonesia adalah pengguna internet. Sedangkan pengguna media sosial di Indonesia tahun 2020 mencapai 160 juta orang, atau 59 persen dari total penduduk Indonesia (Haryanto, 2020).
Van Dijk dalam Nasrullah (2016) mengungkapkan bahwa media sosial adalah suatu platform media yang menitikberatkan pada eksistensi para pengguna, dan memberi ruang kepada para penggunanya untuk beraktivitas maupun berkolaborasi. Dengan kata lain, media sosial merupakan media online berbasis internet yang memberikan kebebasan kepada penggunanya untuk mudah berpartisipasi, berbagi dan menciptakan isi, melalui blog, jejaring sosial, wiki, forum, dan lain-lain, sekaligus memungkinkan pertukaran dan interaksi antar pengguna secara tidak langsung (Nasrullah, 2016). Hal ini dikarenakan media sosial memiliki kemudahan akses komunikasi, baik secara pribadi (individu) maupun secara kelompok (massa).

Sebagai salah satu media berbasis internet (online), media sosial di mana para penggunanya bisa dengan mudah memanfaatkannya untuk memenuhi kebutuhan komunikasi. Dapat disimpulkan bahwa media sosial adalah suatu medium dalam teknologi internet yang memungkinkan para penggunanya saling berinteraksi, bekerja sama, berbagi dan berkomunikasi dengan pengguna lainnya, serta melahirkan ikatan sosial secara virtual (Nasrullah, 2016).

Pengguna media sosial berbagi berita dan informasi untuk memuaskan kebutuhan sosial mereka. Studi sebelumnya juga membahas kepuasan yang terkait dengan penggunaan platform media sosial di antara 
berbagai kelompok usia (Dhir, 2017). Media sosial menjadi salah satu media yang paling di senangi oleh semua kalangan. Tua-muda, bahkan anak-anak banyak menggunakan media sosial dalam kehidupannya seharihari (Soliha, 2015). Media sosial menjadi ruang baru bagi masyarakat (public sphere). Masyarakat saling terhubung satu sama lain dalam jejaring virtual. Meminjam istilah Bourdieu, ruang virtual menjadi semacam arena yang di dalamnya terdapat aktivitas pertukaran informasi dan transaksi. Di dalam media sosial tersebut, terjadi pula distribusi dan pertukaran konten media seperti: data, teks, suara, gambar, dan video informasi, baik dengan orang lain (konsumen) pengguna media sosial maupun perusahaan (Kotler, 2019).

Media sosial merupakan wadah yang paling rentan digunakan untuk menyebarkan konten hoax. Pada tahun 2017, Masyarakat Telematika (Indonesia, 2017) merilis hasil survei nya tentang "Wabah hoax Nasional", menyebutkan bahwa penyebaran konten hoax terbanyak adalah melalui media sosial, di antaranya: Facebook, Twitter, Instagram, dan Path yang mencapai 92,40 persen, menyusul aplikasi chatting seperti: WhatsApp, Line, dan Telegram sebesar 62,80 persen, sementara penyebaran hoax melalui situs web mencapai 34,90 persen. Penelitian yang dilakukan oleh DailySocial.id dan Jackpot Mobile Survey Platform terhadap 2032 pengguna smartphone di seluruh Indonesia, menyimpulkan bahwa media sosial adalah saluran terbanyak dalam penyebaran berita hoax, yaitu persentasenya di Facebook sebanyak 82,25 persen, WhatsApp 56,55 persen, dan Instagram 29,48 persen (Indonesia, 2017).

Kementerian Komunikasi dan Informatika (Kemenkominfo) merilis hasil temuan mereka sepanjang tujuh bulan, sejak Agustus 2018 sampai Februari 2019, terdapat 771 berita hoax yang berhasil diidentifikasi. Temuan ini juga menyebutkan bahwa jumlah konten hoax yang beredar di media sosial terus mengalami peningkatan dari waktu ke waktu. Pada Agustus 2018 ada 25 konten hoax yang teridentifikasi, mengalami peningkatan pada Oktober 2018 menjadi 53 konten hoax, dan pada November 2018 ada 63 konten hoax, hingga pada akhir tahun 2018, pada Desember ada sekitar 75 konten hoax yang teridentifikasi oleh Kemenkominfo. Penyebaran konten hoax meningkat signifikan pada rentang Januari-Februari 2019, setidaknya ada 353 konten hoax yang diidentifikasi oleh Tim AIS Kemenkominfo (Hurabarat, 2019).

Pengaruh perkembangan Teknologi Informasi dan Komunikasi (TIK) bisa menjadi ancaman global bagi Indonesia, terutama yang berkaitan dengan penyebaran berita bohong/hoax (Rosmalinda, 2017). Hoax tidak hanya menyebabkan kegaduhan di tengah-tengah masyarakat, tetapi juga dapat mengganggu proses konsolidasi demokrasi di Indonesia, bahkan berpotensi mengakibatkan terjadinya perpecahan di tengah-tengah masyarakat dan bangsa Indonesia. Dari latar belakang tersebut, penulis tertarik menulis artikel berjudul "Fenomena Media Sosial: antara hoax, Destruksi Demokrasi, dan Ancaman Disintegrasi Bangsa”.

\section{RUANG LINGKUP}

Ruang lingkup permasalahan yang dibahas dalam penelitian ini diantaranya:

1. Rumusan masalah dalam penelitian ini adalah: Bagaimana fenomena media sosial, antara hoax, destruksi demokrasi, dan ancaman disintegrasi bangsa?

2. Penelitian ini membatasi hanya pada pembahasan maraknya kasus hoax di media sosial yang mengancam demokrasi dan keutuhan NKRI.

Hasil dari penelitian ini diharapkan dapat memberi sumbangsih solusi berupa ide, gagasan, serta masukan dalam upaya mengurangi dan memberantas kasus hoax di media sosial.

\section{BAHAN DAN METODE}

Berikut yang menjadi bahan kajian dan metode dalam penelitian ini:

\subsection{Media Sosial: Sebuah Tinjauan Konseptual}

Media sosial atau dalam bahasa lain dikenal dengan istilah Social Network Services (SNS) (Jane Burns, Philippa Collin et.al, 2013). Beda halnya seperti media tradisional yang menggunakan media cetak dan media penyiaran (broadcast), media sosial menggunakan internet (online). Media sosial sebagai sarana komunikasi memiliki fungsi membuat penggunanya untuk berpartisipasi secara aktif dengan memberi feedback secara terbuka, baik berupa informasi maupun respons secara online dalam waktu yang cepat.

Media sosial merupakan suatu wadah untuk berkumpul secara bebas. Bebas dalam artian, bebas dalam aspirasi atau hal lain yang masih bertanggung jawab. Pada intinya, dengan media sosial kita dapat melakukan berbagai aktivitas dua arah dalam berbagai bentuk pertukaran, kolaborasi baik tulisan, visual maupun audio-visual. Media sosial adalah sekumpulan aplikasi berbasis internet dengan teknologi web 2.0 yang diciptakan atas dasar ideologi serta memungkinkan terjadinya penciptaan dan pertukaran. Kaplan dan Haenlein sendiri membedakan media sosial menjadi enam jenis, yaitu collaborative projects, blogs and microblogs, content communities, social networking sites, virtual game words, dan virtual social worlds. Keenam jenis media sosial tersebut dibedakan dari tingkat eksposur masing-masing (Kaplan \& Haenlein, 2010).

Ruang yang di hadirkan dalam media sosial, sejatinya setara dengan ruang sosial. Tempat di mana orang berinteraksi, dan melakukan aktivitas komunikasi. Menurut Boyd dalam (Nasrullah, 2016), media sosial adalah sekumpulan software yang memungkinkan individu dan komunitas untuk berkumpul, berkomunikasi, dan berbagi serta dalam beberapa 
kondisi tertentu saling berkolaborasi. User generated content (UGC) menjadi ciri utama pembeda antara media sosial dengan media massa tradisional, dimana konten dibuat dan ditentukan oleh pengguna, bukan oleh editor sebagaimana pada media massa tradisional (Nasrullah, 2016).

Media sosial memiliki karakteristik khusus yang tidak dimiliki oleh media lainnya. Di antara karakter media sosial, yaitu:

1. Jaringan (Network) Antar pengguna

Media sosial memiliki karakter jaringan sosial. Media sosial dibangun dari struktur sosial yang terbentuk di dalam jaringan internet. Karakter media sosial adalah membentuk jaringan di antara para pengguna. Akhirnya, jaringan yang terbentuk di antara para pengguna ini akan menjadi suatu komunitas atau masyarakat tertentu, dan memunculkan nilai-nilai yang ada di masyarakat sebagaimana ciri masyarakat dalam teori-teori sosial.

2. Informasi (information)

Informasi menjadi entitas yang penting dari media sosial, karena tidak seperti media-media lainnya di internet, pengguna media sosial merepresentasikan identitasnya, memproduksi konten yang berupa teks, gambar, dan lain-lain, serta melakukan interaksi berdasarkan informasi. Di media sosial, informasi merupakan komoditas yang dikonsumsi oleh para pengguna.

3. Interaksi (interactivity)

Interaksi yang terjadi di media sosial minimal berbentuk saling mengomentari atau memberikan respon, seperti me-like. Dalam kajian media, interaksi merupakan salah satu pembeda antara media tradisional dengan media sosial. Media tradisional, para penggunanya cenderung tidak mengetahui satu sama lain, dan bersifat pasif. Sedangkan media sosial, para pengguna bisa aktif saling berinteraksi, baik di antara pengguna itu sendiri maupun dengan pengguna dengan jabatan yang lebih tinggi di masyarakat ataupun pemerintahan sebuah negara (Holmes, 2012).

4. Konten oleh Pengguna (User Generated Content)

Konten oleh pengguna ini menunjukkan bahwa di media sosial, konten sepenuhnya dibuat oleh para pengguna atau pemilik akun media sosial. Konten oleh pengguna ini juga merupakan bukti bahwa di media sosial, pengguna tidak hanya memproduksi konten, tetapi juga sekaligus mengonsumsi konten yang diproduksi oleh para pengguna lain. Misalnya, di Facebook dengan kontennya adalah posting-an status, baik berupa teks maupun gambar, para pengguna bisa mengomentari posting-an status tersebut ibarat komunikasi di dunia nyata.

5. Penyebaran (share/sharing)

Dalam media sosial, praktik penyebaran merupakan ciri khas yang menunjukkan bahwa para pengguna aktif menyebarkan informasi sekaligus mengembangkannya. Maksud dari pengembangan ini adalah konten yang ada mendapatkan respons berupa komentar yang tidak sekadar opini, tetapi juga berdasarkan data atau fakta terbaru dari pengguna media sosial lainnya (Reitz, 2012).

\subsection{Metodologi}

Penelitian ini menggunakan pendekatan kualitatif bersifat deskriptif, yaitu penelitian yang dirancang guna mengumpulkan informasi mengenai keadaan-keadaan yang sedang terjadi. Penelitian kualitatif atau yang biasa juga disebut metode penelitian naturalistis, karena penelitian ini dilakukan pada kondisi yang natural/alamiah (Sugiyono, 2017). Penelitian yang bersifat deskriptif, penelitian terhadap suatu objek dengan tujuan untuk mendeskripsikan atau memberi gambaran terhadap objek yang diteliti melalui data atau sampel yang telah terkumpul (Sugiyono, 2017).

Dalam penelitian ini, penulis mengumpulkan data di antaranya melalui: penelitian terdahulu yang relevan, dokumentasi digital, dokumentasi pemberitaan, dan buku-buku referensi. Setelah data terkumpul, maka penulis melakukan analisis data menggunakan model analisis data interactive model dari Miles dan Huberman (2014), dengan tahapan penelitian sebagaimana terlihat pada gambar 1 .

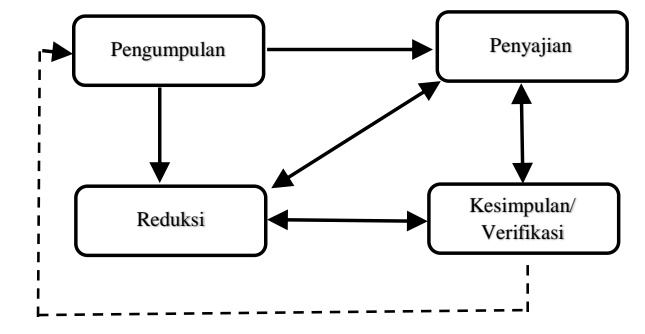
Gambar 1. Interactive Model Analysis Miles \&
Huberman

\section{PEMBAHASAN}

Media sosial menjadi saluran informasi yang berlimpah di tengah-tengah masyarakat saat ini, akibatnya informasi yang bersifat hoax pun menjadi tidak terbendung. Media sosial dan hoax seperti tidak dapat dipisahkan, padahal dampak yang diakibatkan oleh maraknya peredaran konten hoax sangat berbahaya, karena dapat mengancam demokrasi dan persatuan bangsa.

\subsection{Hoax Dalam Media Sosial}

Banyak manfaat yang didapat dari hadirnya media sosial, ragam kegiatan positif dan produktif yang dapat dijadikan contoh bahwa media sosial turut membantu baik di kalangan tua, muda, maupun anak-anak. Begitu pula dengan permasalahan yang ditimbulkan oleh media sosial. Tidak sedikit permasalahan sederhana menjadi rumit dan besar karena media sosial. Penyalahgunaan media sosial juga banyak terjadi, seperti tindak kriminal, kasus penipuan, judi online, penculikan, sampai 
prostitusi online, termasuk juga penyebaran hoax yang dapat merusak kehidupan demokrasi, serta mengancam persatuan dan kesatuan dalam kehidupan bermasyarakat.

Hoax menurut Kamus Besar Bahasa Indonesia (KBBI) adalah berarti berita bohong, kabar dusta, informasi palsu. Istilah hoax populer seiring dengan popularitas penggunaan media sosial (Romelteamedia, 2017). Hoax adalah suatu kebohongan yang dibuat sedemikian rupa oleh orang tertentu yang digunakan untuk kepentingan pribadi, baik secara ekstrinsik maupun intrinsik untuk mengalihkan perhatian atau menutupi dari kebenaran. Hoax sebagai informasi yang sesat dan berbahaya (Chen, 2014).

Pengguna media sosial secara individual, kelompok maupun institusional, dapat bertindak sebagai pengirim maupun penerima pesan dalam komunikasi di dunia maya. Fleksibilitas pemanfaatan media sosial tidak dibatasi oleh status sosial, politik, dan ekonomi seseorang dalam masyarakat. Media sosial memiliki kemampuan dalam menyampaikan pesan kepada khalayak atau pengguna media sosial lainnya dengan cepat dan luas. Kelebihan ini membuat pemberitaan media massa sebagai arus utama menjadi terpinggirkan karena memerlukan proses panjang dan verifikasi (Susanto, 2017).

Dalam jurnal Transformasi nomor 32 tahun 2017, berjudul " hoax dan Banalitas Kejahatan" menyatakan bahwa penyebaran hoax di media sosial mempunyai latar belakang oleh beberapa kepentingan, diantaranya politik kekuasaan, ekonomi (bisnis hoax semisal kasus Saracen), ideologi, sentimen pribadi, atau hanya sekadar iseng belaka (Astrini, 2017). Selanjutnya, berdasarkan hasil riset dari Masyarakat Telematika (Indonesia, 2017), menunjukkan bahwa isu sosial-politik dan SARA merupakan hal yang paling sering digunakan sebagai materi/konten hoax. Isu sensitif mengenai sosial-politik dan Suku, Agama, Ras, dan Antar golongan (SARA), dimanfaatkan oleh oknum penyebar hoax untuk memengaruhi opini publik melalui media sosial. Sebanyak 91,8 persen responden mengatakan paling sering menerima konten hoax yang berkaitan dengan isu sosial-politik, seperti isu pemilihan kepala daerah dan pemilihan presiden. Sedangkan, pada posisi kedua dengan angka 88,6 persen responden menyatakan sering menerima konten hoax yang berkaitan dengan isu SARA.

Contoh hoax dengan konten isu sosial-politik di media sosial adalah yang banyak terjadi menjelang pemilihan presiden tahun 2019 lalu, misalnya kasus hoax penganiayaan Ratna Sarumpaet. Kasus hoax penganiayaan Ratna Sarumpaet pertama kali beredar di Facebook, melalui unggahan posting-an akun Swary Utami Dewi. Unggahan tersebut disertai tangkapan layar dari aplikasi pesan WhatsApp pada 2 Oktober 2018 disertai foto wajah Ratna Sarumpaet yang lebam. Kabar tersebut kemudian menyebar lewat Twitter melalui akun para tokoh, seperti Rachel Maryam, Fadli Zon, dan lainnya. Penganiayaan yang diterima Ratna Sarumpaet kemudian mendapat respons luas, tidak hanya dari netizen, tetapi juga dari calon presiden RI, Prabowo Subianto. Pada Rabu malam, 3 Oktober 2020, Prabowo Subianto bersama para tokoh lainnya dalam koalisi melakukan konferensi pers, dan menyatakan bahwa tindakan terhadap Ratna Sarumpaet adalah tindakan represif dan melanggar hak asasi manusia. Setelah ramai pemberitaan kasus penganiayaan Ratna Sarumpaet tersebut, akhirnya pihak kepolisian dapat membongkar kasus tersebut, dan terbukti hoax. Berikut pemberitaan kasus hoax Ratna Sarumpaet, sebagaimana terlihat pada gambar 2 .

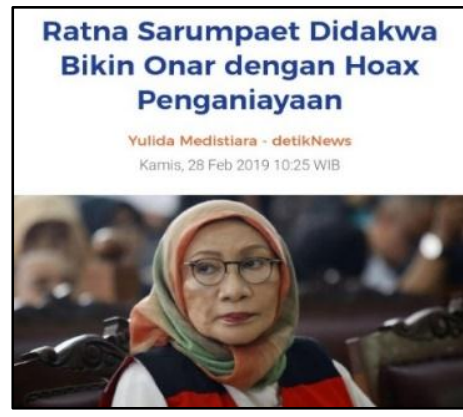

Gambar 2. Pemberitaan Kasus Hoax Ratna Sarumpaet

Mengingat media sosial yang berkembang pesat, ditemukan bahwa faktor sosial memiliki pengaruh yang sangat signifikan dalam berbagi berita palsu di platform media sosial. Sub-faktornya berasal dari pengaruh teman sebaya, serta komentar satir dan lelucon yang memiliki pengaruh besar untuk membagikan informasi palsu. Selain itu faktor-faktor jahat seperti propaganda kebencian juga memicu penyebaran informasi palsu dengan kemungkinan untuk memperoleh keuntungan secara finansial atau merugikan (Celliers, 2020).

Sedangkan contoh kasus hoax bernuansa SARA sekaligus bermotif ekonomi, adalah kasus Saracen. Dari hasil penyelidikan digital forensik, terungkap sindikat ini menggunakan fitur grup dalam Facebook untuk menggalang lebih dari 800.000 akun pengguna Facebook lainnya. Selanjutnya pelaku mengunggah konten provokatif bernuansa SARA, unggahan tersebut berupa teks kata-kata, narasi, tampilan visual/meme, video yang menggiring opini publik untuk berpandangan negatif terhadap satu kelompok masyarakat. Motif sindikat saracen ini adalah meraup keuntungan secara materi (ekonomi) dengan menawarkan jasa penyebaran ujaran kebencian bernuansa SARA di media sosial.

Dalam melaksanakan aksinya, sindikat Saracen ini dilakukan secara terorganisir. Berikut pemberitaan kasus hoax saracen seperti ditunjukkan dalam gambar 3 . 


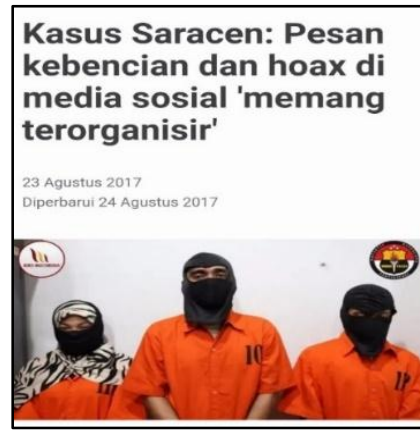

\section{Gambar 3. Pemberitaan Kasus Hoax Saracen}

Melihat banyaknya kasus penyebaran hoax di media sosial saat ini, hal ini dapat disebabkan sebagaimana teori media sosial (Reitz, 2012), yang mengungkapkan karakteristik media sosial, diantaranya: jaringan antar pengguna, informasi, interaksi, konten oleh pengguna, dan penyebaran.

1. Jaringan antar pengguna

Melalui media sosial, seseorang dapat terhubung satu sama lain dengan pengguna media sosial lainnya. Komunikasi yang dilakukan melalui media sosial akan membentuk sebuah jaringan antar pengguna, di mana para pengguna media sosial dapat dengan mudah berkomunikasi tanpa adanya batasan yang jelas dan mengikat. Kemudahan berkomunikasi yang tidak adanya batasan dalam media sosial inilah yang dapat memicu penyebaran konten hoax di media sosial. Karena setiap orang dapat berkomunikasi dengan siapa pun, mengenai apapun, kapan pun, dan dimana pun melalui media sosial.

2. Informasi

Informasi di media sosial sangat berlimpah ruah. berlimpahan informasi di media sosial tersebut tidak diiringi dengan kualitas informasi yang baik dari para penggunanya, sehingga banyak distorsi informasi. Hal inilah yang menyebabkan maraknya kasus penyebaran konten hoax di media sosial, pengguna media sosial harus memilah dan memilih informasi yang baik, positif, dan berkualitas untuk dirinya di tengah banyaknya distorsi informasi di media sosial. Selain itu arus informasi di media sosial mengalir sangat cepat, hal ini sesuai dengan pendapat yang mengatakan, Kecepatan arus informasi memang merupakan keunggulan media sosial (Morgan, Jones, Hodges, 2012).

3. Interaksi

Konten hoax di media sosial terjadi karena adanya saling interaksi antar pengguna media sosial. sifat media sosial adalah interaktif. Kemudahan berinteraksi di media sosial inilah yang memicu seseorang dapat menyebarkan konten hoax (Nasrullah, 2016). Di mana pesan dapat dengan mudah, cepat menyebar, diketahui, dan dibaca oleh banyak orang hanya dengan sekali tekan (one push) ENTER atau KIRIM.
4. Konten oleh pengguna

Karakteristik media sosial inilah yang paling berkontribusi dalam maraknya penyebaran konten hoax di media sosial. Setiap pengguna dapat membuat dan memproduksi sendiri konten pesan atau informasi yang akan disampaikannya melalui media sosial. Lingkungan media digital tidak memperhatikan integritas informasi, ketika informasi itu sudah dipublikasikan secara online, maka siapa pun bebas untuk memodifikasinya. Ketika informasi dimodifikasi, maka disitu terjadi distorsi informasi yang lebih cenderung berpotensi menjadi informasi hoax.

5. Penyebaran

Informasi yang telah terdistorsi, cenderung berpotensi menjadi informasi hoax, disebarluaskan melalui fitur share di media sosial. Hal tersebut mengakibatkan penyebaran konten hoax semakin masif di media sosial. kemampuan share (penyebaran) melalui media sosial ini terbilang sangat praktis. Praktis, karena dapat dengan mudah menjangkau banyak kalangan, mulai dari anak muda, dewasa, pelajar, mahasiswa, komunitas, dan lain-lain.

\subsection{Hoax dan Destruksi Demokrasi}

Hadirnya media sosial banyak memberikan dampak positif bagi kehidupan masyarakat, namun tidak sedikit pula dampak negatifnya. Media sosial, sebagai sebuah platform media berkomunikasi, memberikan wadah bagi publik untuk ungkapkan pendapatnya. Dan ini merupakan elemen terpenting dalam demokrasi, di mana setiap orang memiliki hak yang sama untuk mengungkapkan pendapatnya, dan sekaligus memiliki hak untuk mendapat informasi seluas-luasnya. Namun, media sosial yang awalnya dianggap sebagai sesuatu yang baik untuk perkembangan demokrasi, saat ini justru dipandang sebagai sebuah ancaman laten bagi demokrasi. Hal ini sebagaimana yang pernah ditulis oleh majalah asal Inggris, The Economist, edisi 4-10 November 2017, dalam headline bertajuk "Social Media's Threat to Democracy?", media sosial ancaman terhadap demokrasi.

Hoax seputar isu sosial-politik terutama yang terjadi pada saat pemilihan presiden 2019 lalu dan agenda kontestasi politik lainnya hingga saat ini, memperlihatkan penurunan kualitas bahkan hancurnya demokrasi di Indonesia. Misalnya, dalam kontestasi politik yang seharusnya menjadi ajang pertarungan visimisi, program, ide, dan gagasan tidak lagi menjadi faktor utama, sebaliknya berita hoax, ujaran kebencian dan fitnah yang sengaja dilancarkan untuk menyerang pasangan lawan, politik identitas dengan nuansa SARA lebih banyak digunakan untuk memengaruhi opini publik dan pilihan politik masyarakat, sehingga hasil pemilu yang merupakan indikator utama kualitas demokrasi menjadi tidak baik. Dalam sebuah kontestasi, komunitas biasanya menunjukkan keberpihakan mereka, sehingga berbagai cara dilakukan untuk memarketisasi calon yang 
didukung, sekaligus bersamaan mendemarketisasi calon lawannya (Salam, 2018).

Harus diakui salah satu postulat demokrasi adalah adanya kebebasan informasi, dalam konteks inilah hoax menjadi problem serius demokrasi, karena memunculkan distorsi informasi sehingga pada gilirannya akan mengakibatkan destruksi demokrasi. Kebebasan informasi yang dihasilkan oleh proses demokratisasi saat ini, harusnya dimanfaatkan sebaik mungkin untuk menyemai nilai-nilai dan tradisi demokrasi yang bermartabat. Kebebasan informasi harus menjadi bagian dalam rangka memperkuat konsolidasi demokrasi di Indonesia, bukan sebaliknya justru menjadi penyebab terjadinya destruksi demokrasi yang mencabik rasa kebangsaan melalui produksi dan penyebaran berita hoax.

\subsection{Hoax Dan Ancaman Disintegrasi Bangsa}

Penyebaran hoax yang masif memiliki dampak negatif, apalagi penyebaran hoax sering kali dibarengi ujaran kebencian yang dapat mengancam persatuan dan kesatuan masyarakat dan Bangsa dan Indonesia. Menurut Karyono Wibowo (Direktur Eksekutif Indonesia Public Institute), "Dalam jangka panjang, penyebaran hoax ini dapat menyebabkan krisis kepercayaan, polarisasi ekstrem di tengah-tengah masyarakat, pembelahan relasi sosial, merusak kerukunan dan kebersamaan, menimbulkan konflik sosial yang pada akhirnya mengakibatkan perpecahan (disintegrasi) bangsa".

Para ahli telah mengemukakan bahwa hoax dan missinformasi memainkan peran penting dalam pembentukan polarisasi, terutama selama pemilu. Misalnya, beberapa politisi di Indonesia mengungkapkan kekhawatiran bahwa pemilihan presiden baru-baru ini dipengaruhi oleh propaganda (Nadzir, 2019). Disintegrasi bangsa dapat terjadi karena kondisi masyarakat Indonesia saat ini yang memang sudah terpolarisasi pasca PILPRES 2014 kemudian dilanjutkan PILPRES 2019 (pihak pendukung pemerintah dan pihak oposisi pemerintah) sehingga membuat polarisasi yang terjadi di tengah-tengah masyarakat semakin ekstrem, ditambah penegakan hukum atas kasus-kasus penyebaran hoax dirasa masih jauh dari asas keadilan. Sebagai contoh, kasus hoax yang dilakukan oleh pihak yang berseberangan dengan pemerintah (oposisi) sangat cepat direspons dan ditindaklanjuti, sedangkan sebaliknya kasus hoax yang dilakukan dari pihak pendukung pemerintah, sangat lamban bahkan proses hukumnya cenderung jalan di tempat. Hal seperti demikian membuat tensi pembelahan sosial semakin tinggi, yang dapat mengakibatkan terjadinya kerusuhan sosial, hingga berujung pada terjadinya perpecahan (disintegrasi) masyarakat dan bangsa Indonesia.

\subsection{Pentingnya Literasi Digital Masyarakat dan Solusi Pemberantasan Hoax}

Ada dua alasan mengapa orang lebih cepat percaya dengan berita hoax. Pertama, apabila opini atau sikap seseorang yang dimiliki Sama dengan informasi yang beredar tersebut. Seseorang Akan menerima informasi apapun tentang orang lain, kelompok, produk tertentu, atau suatu kebijakan apabila memiliki ketertarikan pada hal-hal tersebut. Meskipun informasi tersebut tidak benar, maka Akan tetap saja diterima tanpa melakukan konfirmasi apakah informasi tersebut benar atau sebaliknya. Kedua, karena keterbatasan pengetahuan (literasi) yang dimiliki seseorang tentang informasi yang diperoleh, dan keengganan untuk melakukan konfirmasi terhadap berita yang diterima melalui media sosial atau literasi digital (Respati, 2017).

Melihat maraknya produksi dan penyebaran berita hoax di media sosial, maka sangat diperlukan literasi digital bagi masyarakat. Upaya antisipasi penyebaran hoax belum cukup jika tidak disertai kesadaran peningkatan kemampuan literasi digital masyarakat, karena masyarakat umumlah yang akan menjadi pengendali utama atas penyebaran berita hoax tersebut. Literasi digital sangat penting dimiliki dalam memanfaatkan media sosial dengan baik. Lalu lintas informasi yang sangat padat dan banyaknya orang yang mengakses, jangan sampai mengabaikan literasi digital.

Munculnya informasi yang tidak jelas kebenarannya adalah sebagai akibat kurangnya literasi digital di kalangan masyarakat. Oleh karena itu, setiap informasi yang didapat seharusnya disaring terlebih dahulu, sebelum di-sharing (dibagikan). Masyarakat perlu mendapatkan edukasi terkait literasi digital ini sehingga makin cerdas dalam memanfaatkan aneka media digital yang kian berkembang termasuk media sosial. Dengan memiliki literasi digital, masyarakat akan lebih mampu untuk berpikir kritis. Oleh karena itu, masyarakat akan semakin bisa menyaring informasi yang benar atau bohong, berita yang nyata atau rekayasa, maupun konten yang dapat dipercaya atau diragukan.

Selain itu, solusi lain yang dapat dilakukan dalam rangka pemberantasan hoax adalah mendorong Kementerian KOMINFO untuk membentuk badan independen yang melakukan pengecekan apakah berita tersebut bersifat hoax atau tidak. Badan tersebut sekaligus mengelola aplikasi pengecekan hoax yang terakses ke seluruh media online sehingga dapat melawan berita hoax di setiap instansi pemerintah pusat hingga tingkat daerah, meminimalisir keberadaan akun anonim dengan cara memverifikasi akun media sosial menggunakan identitas asli. Selain itu, diharapkan semua lembaga atau institusi, baik pemerintah maupun non pemerintah untuk terus menggalakkan upaya sosialisasi dan kampanye anti hoax serta mendukung konten-konten positif bagi masyarakat Indonesia.

Terakhir, yang paling penting adalah penegakan hukum secara tegas dan berkeadilan untuk menimbulkan efek jera bagi para pelaku pembuat dan penyebar berita hoax. Diperlukan regulasi yang kuat dan jelas (UU ITE) sebagai landasan hukum untuk menangani penyebaran hoax yang sangat masif dan sudah tidak dapat terhindarkan lagi penyebarannya di media sosial. Untuk 
itu sinergisitas atau kerja sama antara aparat keamanan dan elemen masyarakat guna memerangi kasus hoax di Indonesia menjadi sangat penting.

Pengguna media sosial (netizen) harus dapat tumbuh menjadi warga net yang baik (good netizenship). Good netizenship hanya dapat lahir dari budaya santun dalam menggunakan media sosial yang dimiliki dan dipraktikkan oleh para pengguna media sosial, ditambah dengan karakter yang selaras dengan cita-cita luhur dalam rangka merajut kebhinekaan Indonesia yang beragam, serta membangun sinergisitas dalam upaya meningkatkan posisi dan daya saing bangsa Indonesia menuju masa depan yang lebih baik lagi.

\section{KESIMPULAN}

Media sosial menjadi pilihan medium alternatif yang paling banyak diminati orang untuk melakukan komunikasi, sekaligus media sosial menjadi saluran terbesar dalam maraknya penyebaran berita hoax. Konten hoax terbanyak adalah yang berkaitan dengan isu sosial-politik dan SARA, biasanya intensitasnya akan bertambah menjelang agenda kontestasi politik (pemilihan presiden dan pemilihan kepala daerah). Konten hoax dan biasanya juga diikuti dengan ujaran kebencian, jika tidak diantisipasi secara dini dengan baik maka dapat menyebabkan terjadinya penurunan kualitas bahkan hancurnya (destruksi) demokrasi, bahkan berpotensi mengakibatkan terjadinya perpecahan (disintegrasi) masyarakat dan bangsa Indonesia.

Penyebaran berita hoax di masyarakat dapat diantisipasi dengan tiga pendekatan penting, yaitu pendekatan kelembagaan, teknologi, dan literasi. Pendekatan kelembagaan, dapat dilakukan dengan terus menggalakkan komunitas anti hoax, pengawasan dari Kemenkominfo dan aparat kepolisian melalui penegakan hukum berdasarkan UU ITE. Dari sisi pendekatan teknologi, menggunakan aplikasi hoax checker yang bisa digunakan oleh masyarakat untuk melakukan cek kebenaran berita yang terindikasi hoax. Pendekatan literasi, menggalakkan sosialisasi kepada masyarakat mulai dari sekolah hingga masyarakat umum, bukan saja oleh pemerintah tetapi juga oleh seluruh lapisan masyarakat termasuk institusi non pemerintah lainnya, sehingga terbentuk kesadaran literasi masyarakat.

\section{SARAN}

Mengingat perkembangan Teknologi Informasi dan Komunikasi (TIK), setiap waktu mengalami perkembangan yang signifikan, sehingga kajian mengenai media digital (media sosial) senantiasa berkembang. Untuk itu kepada para peneliti lain, diharapkan dapat meneruskan dan mengembangkan penelitian dengan topik serupa, seperti penelitian dengan topik media sosial dan hoax seputar Covid-19 atau pengesahan RUU Omnibus Law Cipta Kerja. Penelitian tersebut dimaksudkan agar dapat terus meng-update perkembangan kajian keilmuan, dan guna mendapatkan temuan-temuan terbaru dalam kajian media sosial dan dampaknya, serta mencari solusi dari permasalahan yang berkaitan dengan topik penelitian.

\section{DAFTAR PUSTAKA}

Amilin, A. 2019. Pengaruh Hoaks Politik dalam Era Post-Truth terhadap Ketahanan Nasional dan Dampaknya pada Kelangsungan Pembangunan Nasional. Jurnal Kajian Lemhannas RI, 7(3), 511.

Astrini, A. 2017. Hoax dan Banalitas Kejahatan. Jurnal Transformasi, II(32), 76-77.

Chen, Y. Y., Yong, S. P., \& Ishak, A. 2014. Email Hoax Detection System Using Levenshtein Distance Method. JCP , 9(2), 441-446.

Haryanto, A. T. 2020. Riset: ada 175, 2 juta pengguna internet di Indonesia. Diakses Dari Https://Inet. Detik. Com/Cyberlife/d-4907674/Risetada1752-Juta-Pengguna-Internet-Di-Indonesia.

Dhir, A., Khalil, A., Lonka, K., \& Tsai, C. C. 2017. Do educational affordances and gratifications drive intensive Facebook use among adolescents?. Computers in Human Behavior, 68, 40-50.

Holmes, D. 2012. Teori Komunikasi (Media, Teknologi dan Masyarakat). Yogyakarta: Pustaka Pelajar.

Ibnu Nadzir, S. S. 2019. Hoax and Misinformation in Indonesia: Insights from a Nationwide Survey. YUSOF ISHAK INSTITUTE ANALYSE CURRENT EVENTS, 92.

Kaplan, A. M., \& Haenlein, M. 2010. Users of the world, unite! The challenges and opportunities of Social Media. Business horizons, 53(1), 59-68.

Hurabarat, D. 2019. Kominfo Jaring 771 Konten Hoax, Mayoritas Terkait Politik. diakses dari https://www. kominfo. go. id/content/det ail/17071/kominfo-jaring-771-kontenhoaxmayoritas-terkaitpolitik/0/sorotan_media.

Kotler, P. T. 2019. Marketing management. Pearson UK.

Celliers, M., \& Hattingh, M. 2020. A Systematic Review on Fake News Themes Reported in Literature. In Conference on e-Business, e-Services and eSociety (pp. 223-234). Springer, Cham..

Indonesia, M. T. 2017. Hasil survey Mastel tentang wabah hoax nasional. Jakarta: Masyarakat Telematika Indonesia. Diambil dari www. mastel. id.Nasrullah, R. (2016). Media Sosial, Perspektif Komunikasi, Budaya, dan Sosioteknologi. Bandung: Simbiosa Rekatama Media. 
Reitz, A. 2012. Social Media's Function in Organizations: A Functional Analysis Approach. Global Media Journal, 5(2), 41-56.

Respati, S. 2017. Mengapa Banyak Orang Mudah percaya Berita Hoax? Dipetik November 2, 2020 , dari https://nasional.kompas.com/read/2017/01/23/1 8181951/mengapa.banyak.orang.mudah.percaya .berita.hoax.?page=all

Romelteamedia. 2017. Pengertian Hoax dan CiriCirinya. Dipetik November 2, 2020, dari http://romeltea.com/pengertian-hoax-dan-ciricirinya

Rosmalinda, R. 2017. Fenomena Penyesatan Berita di Media Sosial. Dipetik Oktober 31, 2020, dari http://www.seskoad.mil.id/admin/file/artikel/Ar tikel_Rury3.pdf

Salam, A. 2018. The Hoax Phenomenon in Indonesian Society: Observing Anti-Diversity Memes since 2014. Humaniora, 30, 315-324.

Soliha, S.F. 2015. Tingkat Ketergantungan Pengguna Media Sosial Dan Kecemasan Sosial (Level of Dependence on Users of Social Media and Social Anxiety). Jurnal Ilmu Komunikasi, 4(1), $1-10$.

Sugiyono. 2017. Metode Penelitian Kualitatif (3 ed.). Bandung: Alfabeta.

Susanto, E. H. 2017. Media Sosial sebagai Pendukung Jaringan Komunikasi Politik. Jurnal ASPIKOM, 3(3), 379-398.

\section{UCAPAN TERIMA KASIH}

Terima kasih disampaikan kepada Kementerian Riset dan Teknologi/Badan Riset dan Inovasi Nasional yang membiayai penelitian ini melalui dana hibah RistekBRIN 2020. Terima kasih juga untuk Ibu Dr. Nani Nurani Muksin, M.Si, selaku dosen pembimbing atas bimbingan dan motivasinya sehingga penelitian dan naskah ini dapat selesai dengan baik. 